\title{
Characterization of the Relationship Between Firms and Universities and Innovation Performance:The Case of Colombian Firms
}

\author{
Fredy A Gomez', Tugrul U Daim², Jorge Robledo³
}

\begin{abstract}
Within the National Innovation System, universities play a key role as the main source of knowledge that supports national productivity and as a system that seeks to improve the competitiveness of firms competitiveness and to find answers concerning market needs in today's fast-changing and globalized economy. Innovation, as a source of competitiveness, is normally supported by a firm's technological capabilities: internal R\&D, external collaborative agreements, and relationships with universities. This study uses a cluster analysis to identify three clusters that represent respectively those firms that interact closely with universities for technology development (which include R\&D projects) and technological learning activities, those firms that interact with universities for technological learning only, and those that do not have any kind of relationship with universities. We also analyze the innovation performance of each cluster. Data here come from the Second Colombian Innovation Survey, which was applied in 2005 to a sample of 6,222 firms. Among the main results, this study shows a higher innovation performance for those firms with relevant linkages for technology learning activities.
\end{abstract}

Keywords: R\&D projects; Technology Collaboration; Technology Transfer.

\footnotetext{
'Hewlett-Packard, Dallas USA

${ }^{2}$ Institute for Sustainable Solutions, Department of Engineering \& Technology Management, Portland State University. ${ }_{3}^{3}$ Jorge Robledo, Universidad Nacional de Colombia- Sede Medellin
}

ISSN: 07 I8-2724. (http://www.jotmi.org) 


\section{Introduction}

The global economy has suffered a dramatic change over the last decades. Today, product life cycles tend to be shorter and the competitiveness of firms competitiveness is higher because of the opening of markets worldwide. Rapid technological change has become a big threat to all kind of firms in all sectors of the economy, putting pressure on these firms to advance in new technologies for their products and processes in order to ensure long-term prosperity and survival (Ali, 1994; Bettis, 1995). The knowledge economy moves forward without providing answers and spreads with no precedent, and the role of the university in this knowledge-based economy has become more important than ever, turning it int a key component of the National Innovation System (Etzkowitz et al., 2000; Eom and Lee, 2010; Lee and Win, 2004; Rycroft and Kash, 2004). Facing this world scenario of accelerated change, enterprises need to be faster and more assertive in the development and implementation of strategic decisions. Only those that change and adapt to the new market and technology conditions will survive and grow; the others will simply disappear.

As a way to respond to all these highly challenging circumstances, enterprises today face the need to innovate in order to be competitive. Enterprises are continuously searching for strategic and effective ways to come up with innovations, and as an answer to this search, collaborative strategies with universities have become a gateway to increase their innovation capabilities, decrease the risks associated with innovation, and accelerate new product development processes (Shilling, 2005). At the national level, countries seek to increase their innovation capability by enlarging the capacity of individual actors like universities, strengthening the linkages between these actors, and building up the overall knowledge infrastructure (Lee and Park, 2006). Nations thus must promote collaboration between university and industry, and thus create favorable conditions for commercial exploitation of the university's output (Abramo et al., 2009).

Through collaboration agreements between firms and universities, firms have rapid access to the complementary experience and knowledge that are necessary to innovate. Chen (1994) highlighted the competitive benefits gained by the firm through the university/industry relationship, representing an important source of innovation. Anderson et al. (2010) pointed out the increasing importance that technology transfer has for the U.S. economy, and at the same time, they encouraged more careful research into this interaction. Daghfous (2004) remarked on the importance of the collaboration between firms and universities as a fast and effective way of capability development. In regard to the benefits for the firms, many authors (Boardman, 2008; Powell et al., 1996; Zucker et al., 1998; Stuart et al., 1999) demon- strated the astonishing growth rates of the firms that have partnerships with universities, compared with those with no universities ties.

Nevertheless, the cultural differences between universities and industry have played an important role in the collaboration agreement, becoming important barriers to collaboration and a constraining factor in the transfer of knowledge (Bjerregard, 2010; Gassol, 2007). Johnson (2008) referred to the triple helix collaboration (academia, government, and industry) as difficult to create and sustain, due to the differences in culture, organization, incentive, and objectives of the various parties involved; nevertheless, he noted that the relationship is vital to the success of regional technology development. Decter et al. (2007) and Markham et al. (1999) also pointed out the difficulties encountered frequently in technology transfer to industry.

Valentin (2000) and Schartinger et al. (200I) each listed a series of challenges in the collaboration process. First of all, firms might have different interests than the universities, putting restrictions on the interaction process. Second, firms tend to hide the results, considering them intellectual property, while universities are under pressure to publish the outcomes. Other difficulties cover the codification of the knowledge, from tacit to more explicit knowledge. Veugelers and Cassiman (2005) mentioned a series of situations occuring during this relationship, such as a high degree of uncertainty, significant information asymmetry between firms and universities, high transaction costs in the knowledge exchange, a certain amount of spillover to other market actors, and financial restrictions.

The interaction between firms and industry does not always extend to contract-based R\&D collaboration, especially if the study focus is on developing countries. There is a need to cover other types of interactions, either formal or informal, between these two parties. The range must be covered by a broader scale, from conferences and seminars (learning activities) to more formal ones such as public $R \& D$ program collaborations (Nikulainen and Palmberg, 2010; Schartinger et al., 200I). Shilling (2005) explained how agreements between firms and universities usually focus on three different types of collaboration: strategic alliances, licensing, and collective research organizations. Lee and Win (2004) summarized the different mechanisms used by firms for technology transfers such as collegial interchange (conferences and publications), consultancy in technical services, exchange programs, joint ventures of R\&D, cooperative R\&D agreement,s licensing, contract research science, and research parks and training. For this particular study, the relationship between university and industry is focused on technological development activities (TDA) and technological learning activities (TLA). TDA are defined as activities that aim to bring to 
practice concepts, ideas, and methods needed to acquire, assimilate, and incorporate new knowledge in the organization; they include capital incorporated technologies, management technologies, transversal technologies, and research and development projects (R\&D). TLA are more focused toward technology training (Colombia, 2005).

Despite all the literature published and the different approaches undertaken to understand the phenomenon of the firm-university interaction, this study focuses on the main factors that characterize the interaction between firms and universities along with a brief analysis of the incidence of the firms' innovation performance in a developing country. None of the literature encountered was concentrated in any non-OECD country. Factors usually refer to variables like size of the firms, characteristics of such firms, role of governmental policies, and so on, and they will be studied in the next section.

\section{Factors That Characterize the Firm-University Re- lationship}

There are a series of studies that focus on exploring the factors that rule the firm-university relationship as related to innovation outcomes (Spencer, 200 I; Cohen et al., 2002); all of them have concentrated on countries from the OECD. Using the Eurostat Community Innovation Survey (CIS) and the United Kingdom Innovation Survey, the OECD (2005) extracted the key factors that are determinants for the firm-university relationship: the institution's reputation, mastery in the topic, and historical collaboration with other institutions.
Bailleti and Callahan (1993) and Prabhu (1999) listed the factors that firms based in high technology have in establishing relationships with universities: the technological discontinuities, the convergence of technology and markets, the rise of technological standards, and the scale increases required in R\&D for global markets. Eom and Lee (2010) also expressed the idea that existing studies have tended to focus more on firm and sectorial characteristics, such as R\&D intensity, firm size, science-basedness, and intellectual property right regimes, but analysis of the contribution of governmental research institutes to the industry-university relationship and the firm's performance has been limited.

Laursen and Salter (2004) also noted that despite the extremely valuable knowledge gained in firm-university relationship studies, such studies are biased in the direction of a limited number of technological environments such as the life sciences and suggested a series of cross-industry studies be undertaken in order to find accurate outcomes of the different sectors' participation with universities. Cohen et al. (2002) explainedthe variety of mechanisms used by firms to access and interact with the university system; their study used only a sample of firms with industrial R\&D facilities and was therefore heavily biased towards high technology companies, and their conclusions cannot be extended to firms from emergent economies. In contrast, this study identifies a series of characteristics that represent the industry/university interaction like the size of the firm, the R\&D intensity, the firm's openness, the industrial sector, and the specific government support. These are represented in Figure I and explained in the next sections.

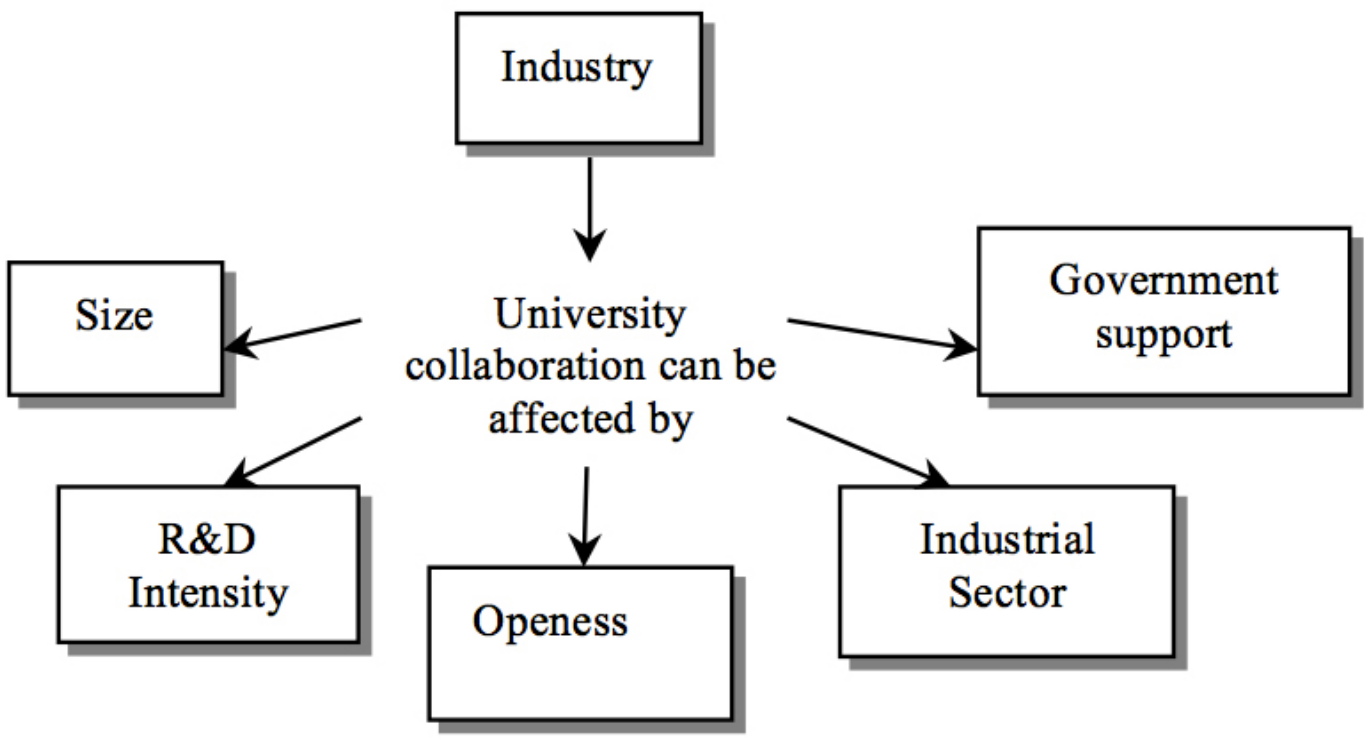

Fig. I. Firm characteristics in university collaborations

ISSN: 07I 8-2724. (http://www.jotmi.org)

Journal of Technology Management \& Innovation (c) Universidad Alberto Hurtado, Facultad de Economía y Negocios. 


\section{Firm Size}

In exploring the size of firm, researchers (Cohen et al., 2002; Mohnen and Hoareau, 2002; Laursen and Salter, 2004; Lopez, 2008; Segarra-Blasco and Arauzo-Carod, 2008) have found a high propensity that large firms will to establish strong relationships with univerisities. This connection is due to the high absortion capacity that characterize large firms (Lopez, 2008). However, Cohen et al. (2002) found that new and small firms, specifically start-ups, can also have a link with universities, since their ideas or products may come directly from an educational institution. There are also studies that show how these small firms are more eager for external cooperation with universities because they lack internal resources.

Eom and Lee (2010) found little evidence of the relationship between the size of the firm and the decision to establish relationship with universities. They found this relationship was positive but insignificant. Fontana et al. (2006) confirmed the hypothesis that larger firms and start-ups have a higher probability of benefiting from academic research. Mohnen and Hoareau (2002) found that large firms are generally more likely to collaborate with other research parties, especially with public institutions. Segarra-Blasco and Arauzo-Carod (2008) found that small and innovative firms in Spanish manufacturing and service industries find it very difficult to find R\&D partners. Frequently, big firms focus this relationship on the development of non-core technologies, while small and medium enterprises generally develop this relationship as a way to guarantee their subsistence (Santoro and Chakrabarti, 2002). Finally, Laursen and Salter (2004) concluded that the capability of firms to draw from university research increases with the size of the organization.

\section{R\&D Intensity}

In regard to R\&D intensity, Fontana et al. (2006), Miotti and Sachwald (2003), and Mora et al. (2004) concluded that firms with the highest investment of money and time in R\&D activities are most likely to have strong collaborations with universities. Arundel and Geuna (2004) found that firms with intense R\&D activities have more chances to cooperate with. Hall and Bagchi-Sen (2007) as well as Baghci-Sen (2004) also found a positive relationship between R\&D expenditure and innovation performance.

On the other hand, Eom and Lee $(2010)$ found that the relationship between universities and firms according to $R \& D$ efforts sometimes is not clearly defined or is difficult to establish: if the firm has high R\&D capacities, it is expected to absorb external knowledge easily; nevertheless, it could happen that since they have plenty of capability, these firms may want to try substituting external cooperation for in-house effort.
Cohen and Levinthal (1989) established that by investing in R\&D, the firm can develop new products and process and build up relationships outside. Those firms that invest in R\&D are likely to absorb the information developed outside the firm. George et al. (2002) stated that firms with university linkages were expected to have lower R\&D expenses than firms without universities linkages; i.e., firms with university linkages spent less (per employee) on R\&D than firms without these linkages. Laursen and Salter (2004) found that R\&D expenditures encourage firms to seek knowledge from universities. Segarra-Blasco (2008) concluded that a firm's internal R\&D activities increased that firm's probability of cooperating with public and private partners. Adeoti and Adeoti (2005) pointed out that lack of resources like human and infrastructure resources for R\&D activities in firms represents common constraints in the firm-university interaction, so by increasing these R\&D resources, the interaction would be closer.

\section{Openness}

The variable related to a firm's openness expresses the willingness to search for external knowledge and to screen the outside world using publication databases. Fontana et al. (2006) suggested that acquiring knowledge through the screening of publications affects the probability of signing an agreement with a university, but not the level of collaboration developed. Laursen and Salter (2004) found that the more the firm establishes initiatives to collaborate and explore innovation through external sources, the more the firm is likely to collaborate with universities. These authors found a strong relationship between the firm's openness and the probability of using university knowledge in innovation activities. Firms who are more open in the way they search for new ideas for innovation are also more likely to draw from universities.

Eom and Lee (2010) explained the level of engagement in cooperation with external partners by explaining the limitations of internal resources like financial capital, technology, and human capital. Geisler (1995) found that the more the universities and firms recognized the need for each other, the higher the probability of having agreements for projects. Nevertheless, other studies present the opposite: firms usually look for partners other than universities because of the mismatch in research interests, so the high level of a firm's openness does not always correspond to a high level of cooperation with universities (Santoro, 2000; Freel and Harrison, 2006) 


\section{Industrial Sector}

In respect to the influence that certain economic sectors have on the firm-university relationship, many studies have found evidence concerning the firm's attitude about collaborating with university according to the sector it belongs. For instance, Laursen and Salter (2004) established that only a few economic sectors show a marked support from universities to produce innovation, whereas others remain highly isolated from it. This may explain the fact that some industrial or economic sectors with highly developed technologies use science outcomes from the university to innovate (Klevorick et al., 1995).

Pavitt's study presented in 1984 found that sectorial characteristics mark an importance influence in industry-university cooperation. In another study byf the same author (1997), Pavitt explained that not all the research carried out by universities is relevant to the different economic sectors. Different industrial sectors face different technological opportunities, and that accounts for the strategic differences in which university and what kind of knowledge firms pursue (Klevorick et al., 1995). Finally, Segarra-Blasco and ArauzoCarod (2008) emphasized high-technology sectors in both manufacturing and services as the most likely industrial sector to cooperate with universities.

\section{Governmental support}

Governmental stimulus is usually seen as impacting the relationship between firm and university in a positive way, and this intervention has determined the success or failure of many cooperative projects. The cultural differences between the firms and universities make necessary the participation of a third party to smooth the relationship. The participation of the government can help finish the cooperative relationship successfully (Mohnen and Hoareau, 2002). The government may help firms to acquire basic or core technology from universities by funding research programs.

Capron and Cincera (2003) found that those firms that use the governmental stimulus tend to establish cooperative relationships with public research organizations. Other studies (Bayona et al., 200I; Miotti and Sachwald, 2003) also found that firms with access to public funds for R\&D activities tend to cooperate more with universities.

\section{Innovation}

Finally, in this study, the firm's innovation performance is the measure that justifies the relationships between universities and firms.An important question is whether the relationship

\begin{tabular}{|c|c|}
\hline \multicolumn{2}{|l|}{ Relationship Variables } \\
\hline Variable & $\begin{array}{c}\text { Variable } \\
\text { Type }\end{array}$ \\
\hline Value-funded in TDA by Colciencias* & Quantitative \\
\hline Value-funded in TDA by university & Quantitative \\
\hline Value invested in technological learning by SENA** & Quantitative \\
\hline Value invested in technological learning by university & Quantitative \\
\hline $\begin{array}{l}\text { Value invested in technological learning by technolog- } \\
\text { ical institute }\end{array}$ & Quantitative \\
\hline \multicolumn{2}{|l|}{ Performance Variable } \\
\hline $\begin{array}{l}\text { Number of innovations both product and process in } \\
2003-2004\end{array}$ & Quantitative \\
\hline \multicolumn{2}{|l|}{ Characterization Variables } \\
\hline Size of the firm (micro, small, medium and large) & Nominal \\
\hline Number of employees in R\&D activities & Quantitative \\
\hline Number of patents requested by the firm & Quantitative \\
\hline Number of external relationships to carry out ADT & Quantitative \\
\hline International Standard Industrial Classification (ISIC) & Nominal \\
\hline Value-funded in TDA by public entities. & Quantitative \\
\hline
\end{tabular}

Table I.Variables from the model.

*Colciencias: Colombian Institute for the Development of Science and Technology ** SENA: National Learning Service of Colombia

ISSN: 07 I8-2724. (http://www.jotmi.org)

Journal of Technology Management \& Innovation (c) Universidad Alberto Hurtado, Facultad de Economía y Negocios. 
with universities has any influence on the firm's innovation. Fontana et al. (2006) did not find any correlation between innovation performance and the level of relation between firms and universities. According to these authors, there is no evidence of a significant correlation between product innovation and engagement in collaborations with public research organizations.

Some authors have stated that because of the characteristics of the knowledge transferred from universities, this may not have a direct impact on the innovation or new product releases of the firms, but its impact is more on R\&D decisionmaking (management of research projects) (George et al., 2002). Monjon and Waelbroeck (2003) found that cooperation with universities increases the probability of radical innovation, while spillover from universities does not. Mohnen and Hoareau (2002) found a positive relationship between the introduction of radical product innovations and the extent of reliance on public research organizations. Laursen and Salter (2004) found only partial support for the hypothesis that firms that are more innovative, in terms of product innovations, are those that rely more on public sources in universities. Segarra-Blasco and Arauzo-Carod (2008) concluded that firms that performwell in product and process innovation have a high propensity to engage in R\&D cooperation agreements.

\section{Methodology}

Data were obtained from the Second Colombian Innovation Survey, which was applied in 2005 to a sample of 6,172 in 2003 and 2004. The study's methodology is guided by a nonsupervised approach to treating data; statistical exploratory techniques are used, such as Multivariate analysis techniques (factor and cluster analysis). These tools help identify profiles of firms according to their characteristics and help diminish the complexity of the analysis by grouping the firms in clusters. In order to make comparisons among obtained clusters, statistical procedures such as mean comparison tests are used. Specifically, the Kruskall Wallis test and the Post Hoc Dunnett test were used to make the comparison of the means.

\section{Results}

Table I shows three sorts of variables that we selected to carry out the study from the survey: relationship variables, performance variables, and characterization variables. The relationship variables measure directly the grade of relationship between firms and universities through the funding of TDA and TLA; therefore, if the firm qualifies or scores high in one of these variables, it shows a strong relationship with universities. On the other hand, the performance variable is represented by the number of innovations that firms have achieved in 2003 and 2004 both in products and processes (Table I).

Finally, the characterization variables represent the main "characteristics" or profiles that a firm has in respect to variables like size of the firm, R\&D efforts, external linkages, and industrial sector, and at the same time, they also help validate the hypotheses. The size of the firms is characterized by the number of employees: if the firms have fewer than 10 employees, the firm is micro; if it has between 10 and 50 employees, it is small; if it has between $5 \mathrm{I}$ and 200 employees, it is medium; and finally if the firm has more than 200 employees, it is considered large.

In order to apply the statistical exploratory techniques, which aim to reduce the number of variables and to create clusters, five relationship variables related to the direct relationship between firms and universities were selected: Relationships Variables (See Table I). Factor analysis was conducted to understand the underlying constructs better.

\begin{tabular}{|l|l|l|l|}
\hline \multicolumn{1}{|c|}{ Code } & \multicolumn{1}{|c|}{ Variable } & \multicolumn{1}{|c|}{\begin{tabular}{c}
\multicolumn{1}{|c|}{ Factor } \\
$\mathbf{1}$
\end{tabular}} & $\begin{array}{l}\text { Factor } \\
\mathbf{2}\end{array}$ \\
\hline CAPUNI & $\begin{array}{l}\text { Value invested in technological learning by university in } \\
2003-2004\end{array}$ & 0,814 & 0,099 \\
\hline CAPTECN & $\begin{array}{l}\text { Value invested in technological learning by technological } \\
\text { institute in 2003-2004 }\end{array}$ & 0,801 & 0,099 \\
\hline CAPSENA & Value invested in TLA by SENA in 2003-2004 & 0,775 & $-0,099$ \\
\hline ADTCOLC & Value-funded in TDA by Colciencias in 2003-2004 & $-0,003$ & 0,719 \\
\hline ADTUNI & Value-funded in TDA by university in 2003-2004 & 0,06 & 0,715 \\
\hline
\end{tabular}

Table 2. Factor Analysis.

Extraction method: Principal Component Analysis

Rotation method:Varimax with Kaiser Normalization (converged with 3 iterations)

ISSN: 07I 8-2724. (http://www.jotmi.org)

Journal of Technology Management \& Innovation (c) Universidad Alberto Hurtado, Facultad de Economía y Negocios. 
As can be inferred from Table 2, Factor I seems to have affinity with those variables related to TLA efforts that firms establish with universities, and Factor 2 represents variables related to TDA efforts. Factor $I$ is called Technological Learning Activities Efforts (TLA efforts) and Factor 2 Technological Development Activities Efforts (TDA efforts). Figure 2 represents the outcomes from Table 2. The factor analysis found a clear relationship between those variables that are aimed towards TLA and those aimed towards TDA.

Consequently, a cluster analysis was carried out over the scores obtained in the factor analysis. Table 3 and Figure 3 show the different clusters and their respective names obtained by means of the K-means methodology. This table reveals that the procedure has encountered three clusters: Isolated Firms, Trained Firms, and Related Firms.

\begin{tabular}{|c|c|}
\hline Cluster & $\begin{array}{c}\text { Number } \\
\text { of firms }\end{array}$ \\
\hline Isolated Firms & 3933 \\
\hline Trained Firms & 58 \\
\hline Related Firms & 12 \\
\hline
\end{tabular}

Table 3: Identified Clusters

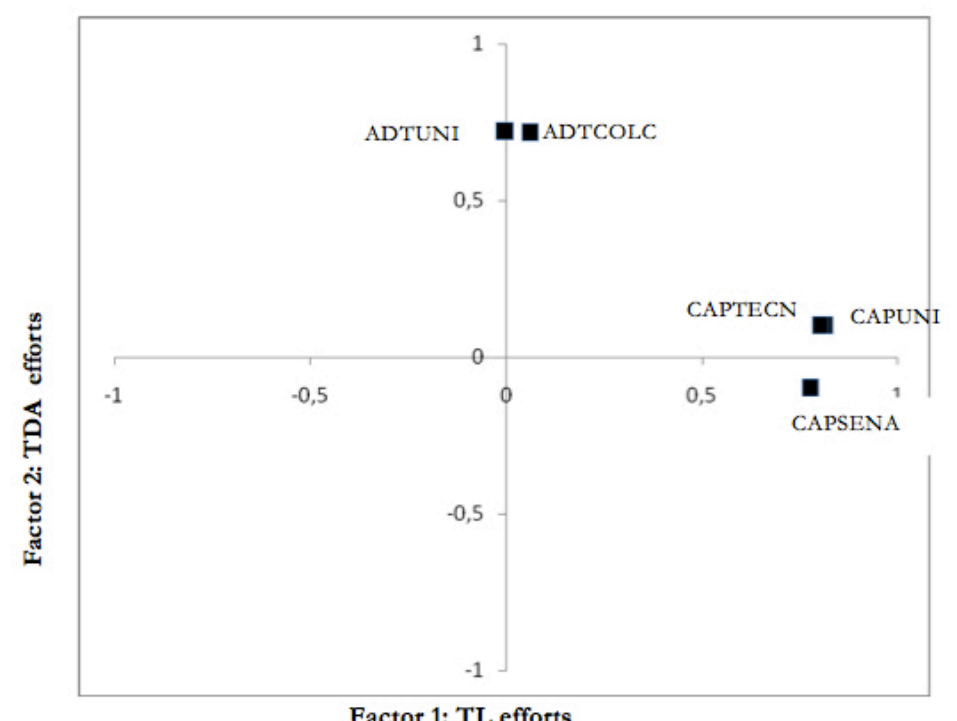

Factor 1: TL efforts

Figure 2: Factors representation

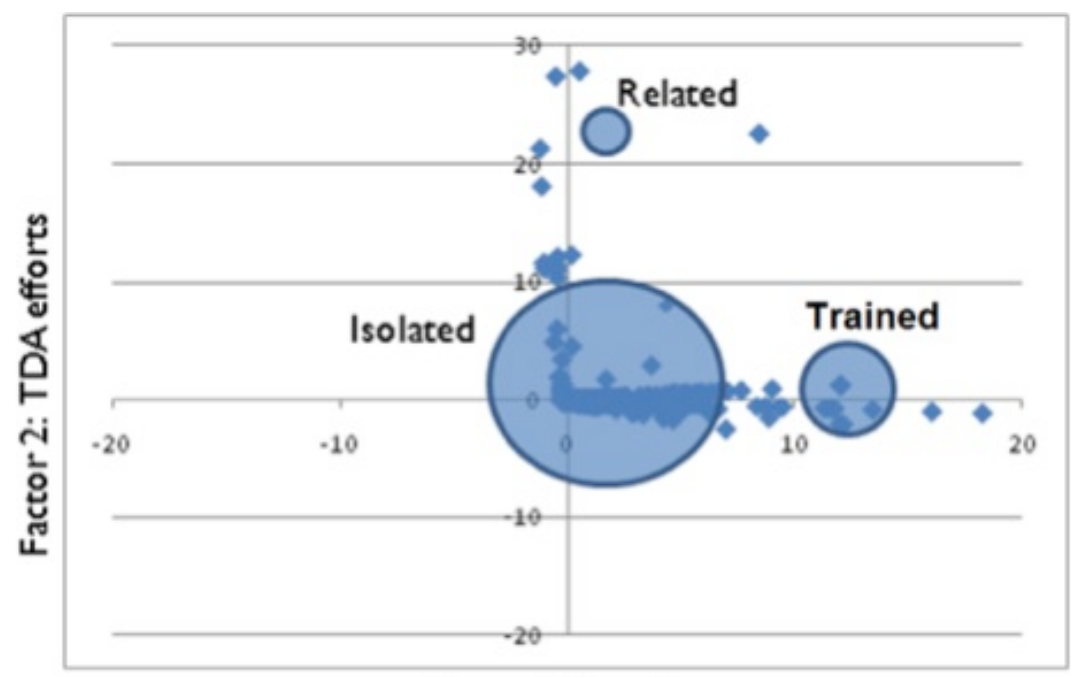

Factor I:TL efforts

Figure 3 Cluster Analysis

ISSN: 07 I8-2724. (http://www.jotmi.org) 
So we would like to evaluate the following hypotheses:

- $\quad$ There is a difference among the three clusters in the number of employees for R\&D activities.

- $\quad$ There is a difference among the three clusters in the number of external relationships to develop TDA

- $\quad$ There is a difference among the three cluster in the amount of money invested by public organizations

- $\quad$ There is a difference in the innovation performance among the three clusters.
The following variables will be explored for testing the hypotheses (Table 3.5):

As expected from the Colombian experience, Isolated Firms cover most (98\%) of the companies under analysis (3933 out of 4003). For each characterization variable (number of employees in R\&D, number of external relationships, and amount of money for financing TDA), the study identified the mean differences among the clusters; results are presented in Table 4. In the case of the nominal variables (size of the firm), Table 5 shows the outcome for each cluster and Figure 4 its respective graphical representations.

\begin{tabular}{|ccc|}
\hline No & \multicolumn{1}{|c|}{ Hypothesis } & Variables \\
\hline 1 & $\begin{array}{l}\text { There is a difference among the three clusters in } \\
\text { the number of employees for R\&D activities. }\end{array}$ & Number of employees in R\&D activities \\
\hline 2 & $\begin{array}{l}\text { There is a difference among the three clusters in } \\
\text { the number of external relationships to develop } \\
\text { TDA }\end{array}$ & Number of external relationships to develop TDA \\
\hline 3 & $\begin{array}{l}\text { There is a difference among the three cluster in the } \\
\text { amount of money invested by public organizations }\end{array}$ & Value-funded in TDA by public organizations (US \\
& Dollar).
\end{tabular}

Table 3.5:The following variables will be explored for testing the hypotheses.

\begin{tabular}{|c|c|c|c|c|c|}
\hline Variables & $\begin{array}{c}\text { P-value } \\
\text { (mean com- } \\
\text { parison) }\end{array}$ & $\begin{array}{c}\text { Isolated } \\
\text { (1) }\end{array}$ & Trained & Related & Dunnett test \\
\hline $\begin{array}{c}\text { Number of employees in } \\
\text { R\&D activities }\end{array}$ & 0,000 & 1,1 & 4,7 & 2,4 & $2>1 *$ \\
\hline $\begin{array}{c}\text { Number of relationships } \\
\text { or contracts with external } \\
\text { entities for TDA }\end{array}$ & 0,000 & 0,4 & 1,2 & 2 & $2>1 * *$ \\
\hline $\begin{array}{c}\text { Value-funded by the public } \\
\text { sector for TDA (US dollars) }\end{array}$ & 0,000 & $30.131 \$$ & $171.754 \$$ & $30.025 \$$ & $1=2=3 * *$ \\
\hline
\end{tabular}

Table 4. Quantitative Characterizing Variables

* Significance level of $5 \% * *$ Significance level of $10 \%$

\begin{tabular}{|c|c|c|c|}
\hline Size of the firm & Isolated & Trained & Related \\
\hline Variables & 419 & 0 & 1 \\
\hline Micro & 1.996 & 0 & 3 \\
\hline Small & 1.128 & 6 & 5 \\
\hline Medium & 390 & 52 & 3 \\
\hline Large &
\end{tabular}

Table 5. Qualitative Charaterizing Variables: Size and Type of the firm

ISSN: 07 I8-2724. (http://www.jotmi.org)

Journal of Technology Management \& Innovation (c) Universidad Alberto Hurtado, Facultad de Economía y Negocios. 


\section{Cluster I: Isolated Firms}

The first cluster, called Isolated Firms, covers most of the companies under consideration (3933 out of 4003); therefore, it represents the average Colombian firm. Its name comes from the scarcity of these relationships in collaborative activities with universities either for TL or TDA. In this cluster, we found that $74 \%$ of the sample did not have any contact either for TLA or TDA, since technological transfer never happens in these relationships.

In respect to the characterization variables, Table 4 shows that Isolated Firms are mainly represented by firms with the fewest number of employees in R\&D activities, situations that makes this cluster the weakest in producing important outcomes in R\&D. In addition to this, their external relationship for TDA is less statistically significant than the Trained Firms cluster (Table 4). This cluster is dominated by small and medium enterprises, and the capital comesmainly from national sources (see Figures 3 and 4).

Finally, Isolated Firms have a high representation of the ISIC I8I (International Standard Industrial Classification code), which represents those firms focusing on manufacturing clothes (except leather fashion accessories); at the same time, this sector represents one of the most largest manufacturing industries in the country. The number of firms found in this ISIC was 45 I out of 3933, nearly $12 \%$ of the cluster.

\section{Cluster 2.Trained Firms}

Trained Firms have the most outstanding results in TLA activities, either through universities, technological institutions, or technical institutions. Their main characteristic is their high investment in TLA and this is why we called them Trained Firms. Without doubt, this is the most dynamic cluster found in the study. Table 4 shows the outstanding results of this cluster not only in R\&D efforts through the number of employees in these activities, but also in external relationships, the last one measured as the number of relationships that these firms have with external parties.

In respect to the nominal characterization variables, Figure 4 presents the important participation of foreign capital in these firms (38\% of the cluster are considered foreign firms according to the classification methodology adopted in this work). This cluster is mainly composed of large enterprises; $90 \%$ had more than 200 employees.

Finally, there is not an important representation of any industrial sector in this cluster according to the International Standard Industrial Classification, but it is important to mention sectors 242 (Manufacturing of other chemical products) and 269 (Manufacturing of non metallic mineral products) with 7 and 5 firms, respectively, in this cluster. The chemical products industry is a well-known sector with numerous university agreements because of their science-based products.

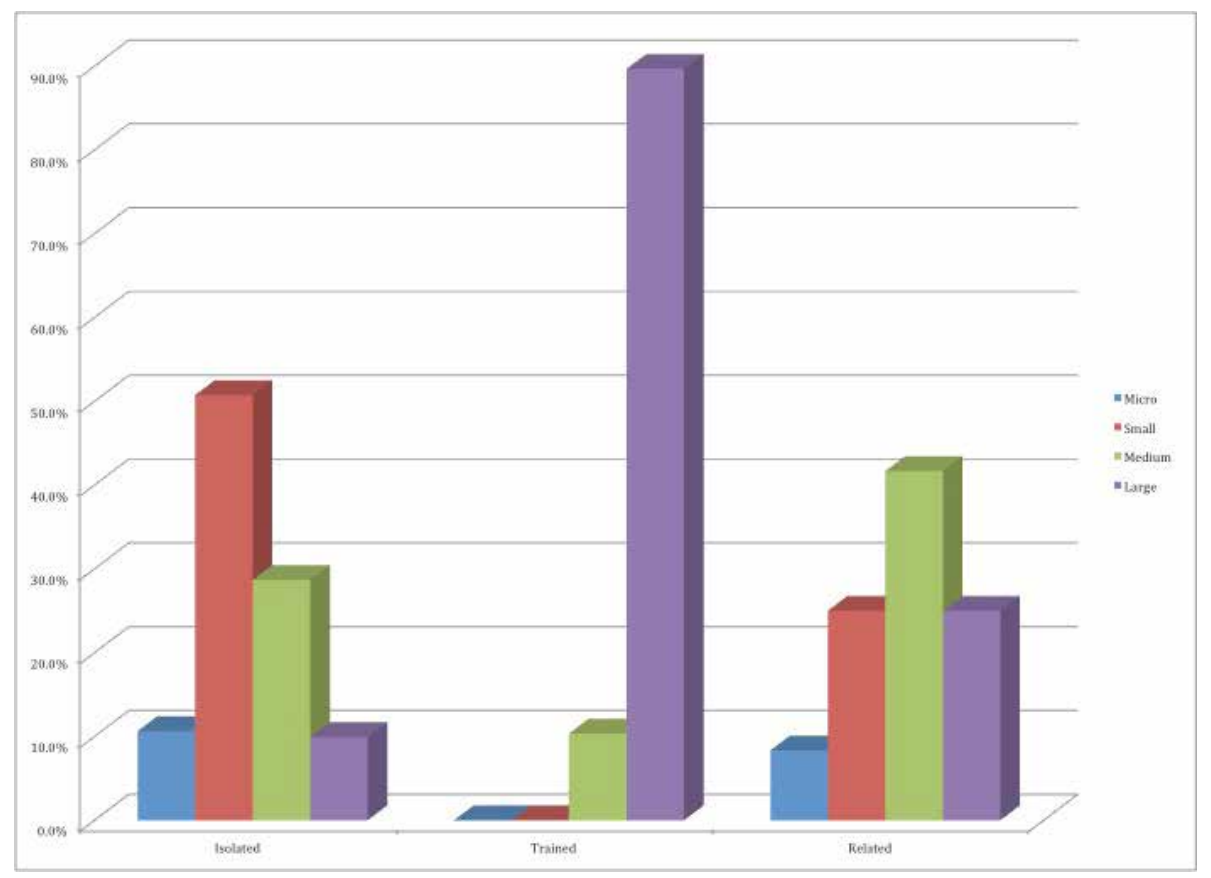

Fig. 4 Characterizing Variables: Size of the Firm

ISSN: 07 I8-2724. (http://www.jotmi.org)

Journal of Technology Management \& Innovation (c) Universidad Alberto Hurtado, Facultad de Economía y Negocios. 


\section{Cluster 3. Related Firms}

The particular feature of this cluster is the high relationship that these firms have established with universities both for TDA and TLA. So, unlike the other two clusters, Related Firms has a strong relationship especially for TDA and represents the smallest cluster, with only 12 firms in the group.

An interesting outcome of the study is that this cluster does not belong to a specific size of firm; in fact, the 12 firms are distributed uniformly through micro, small, medium and large enterprises with a small predominance of mediumsized enterprises (40\%) (Figure 3 ). What the study does show is the dominance of national firms (type of the firm), as II out of the 12 firms in this cluster have above $50 \%$ of their capital originating in Colombia (Fig. 5). Finally, there is no relevant participation of any industrial sector in this cluster. It is important to analyze further the small number in this cluster (only 12 firms out of 4003) and the effect of this on the results and valid conclusions.

\section{Innovation Performance}

As stated at the beginning of the study, our aim was to characterize firms in respect to their relationship with universities, and to consequently find the influence of that on innovation performance. Table 6 presents the outcomes after comparing the average number of innovations for each cluster. We found that that the Trained Cluster was statistically more significant than the Isolated Firms. In other words, the most dynamic cluster found in the study for variables such as external relationships and R\&D efforts is at the same time the cluster with the highest number of innovations for the years 2003 and 2004 in Columbia.

Isolated Firms face a critical situation related to innovation performance, since $85 \%$ of the firms from this cluster did not mention any innovation in years 2003 and 2004 (it was also found that $74 \%$ of the firms in this cluster did not have any contact with universities), showing a very poor dynamic process towards the production of innovation either in products or processes. The rest of the firms (15\%) were characterized by product innovation or a combination of product and process innovation.

\begin{tabular}{|c|c|c|c|c|c|}
\hline Variables & $\begin{array}{c}\text { P value (mean } \\
\text { comparison) }\end{array}$ & Isolated (I) & Trained & Related & Dunnett test \\
(3) & & (2) & \\
\hline $\begin{array}{c}\text { Average number of product and } \\
\text { process innovations in 2003-2004 }\end{array}$ & 0,000 & 0,38 & 1,34 & 0,5 & $2>I^{*}$ \\
\hline
\end{tabular}

Table 6. Average Innovation for each cluster.* Significance level of $5 \%$

\begin{tabular}{|c|c|c|c|c|c|c|}
\hline \multirow[b]{2}{*}{ Variables } & \multirow{2}{*}{$\begin{array}{l}\text { P Value (Mean } \\
\text { Comparison) } \\
\text { KruskalWallis }\end{array}$} & \multicolumn{3}{|c|}{ Cluster } & \multirow{2}{*}{$\begin{array}{l}\text { Dunnett } \\
\text { Test }\end{array}$} & \multirow[b]{2}{*}{ Hypothesis } \\
\hline & & $\begin{array}{l}\text { Isolated } \\
\text { (1) }\end{array}$ & $\begin{array}{l}\text { Trained } \\
\text { (2) }\end{array}$ & $\begin{array}{l}\text { Related } \\
\text { (3) }\end{array}$ & & \\
\hline $\begin{array}{l}\text { Average Number of } \\
\text { Employees in R\&D }\end{array}$ & $0.0001^{*}$ & 1.1 & 4.7 & 2.4 & $2>1^{*}$ & 1 \\
\hline $\begin{array}{l}\text { Average Number of } \\
\text { external relationships }\end{array}$ & $0.0001 *$ & 0.4 & 1.2 & 2 & $2>1^{* *}$ & 2 \\
\hline $\begin{array}{l}\text { Average Value-funded in } \\
\text { TDA by public } \\
\text { organizations (US Dollar). }\end{array}$ & $0.0001 *$ & 30,131 & 171,754 & 30,025 & N.S. & 3 \\
\hline $\begin{array}{l}\text { Average Number of } \\
\text { innovations (Products } \\
\text { and Processes) }\end{array}$ & $0.0001 *$ & 0.38 & 1.34 & 0.5 & $2>1^{*}$ & 4 \\
\hline${ }^{*}$ Significance level of $5 \%$ & \multicolumn{4}{|c|}{ ** Significance level of $10 \%$} & & \\
\hline
\end{tabular}

Table 8 - Hypothesis Testing Results

ISSN: 07 I8-2724. (http://www.jotmi.org)

Journal of Technology Management \& Innovation (c) Universidad Alberto Hurtado, Facultad de Economía y Negocios. 
Related Firms, which showed high values in relationship variables with universities, also did not score very well in innovation performance. Only 3 out of the 12 firms had innovation results. As stated above, the small number of firms in this cluster does not allow us to draw a valid conclusion. The study sought evidence of the firms with strong relationships with universities having strong innovation performance, and partially, we found that. Although Related Firms should have the highest innovation performance, the Trained Firms, which have relationships with universities with TLA, are the ones with the best innovation performance. Trained Firms, which showed strong relationships with universities, are the strongest with regards to innovation performance, both in product and process, and this makes them the benchmarks of the study. At the same time, these firms are characterized by a high number of employees in R\&D activities as well as by high initiative in creating links with external entities to carry out TDA, validating the hypothesis of the study, as these values are statistically significant higher than for the other clusters.

Tables 8 and 9 provide a summary of the hypothesis testing results.

\section{Conclusions}

Among the different sized firms, large firms are more likely to establish linkages with universities than small and medium enterprises; in other words, the Trained Cluster, which has outstanding relationships with universities, is mainly made up large firms. There is no a clear evidence that micro, small, and medium enterprises have strong relationships with universities.
The Trained Firms cluster becomes the benchmark group of this study because of its innovation performance. In addition to this, it is important to mention the significant superiority of the Trained Firms in variables like number on employees in R\&D activities and number of external relations to produce TDA, which can explain the relevant outcomes that these firms have in innovation processes. Most of the firms belonging to this cluster are large firms with more than 200 employees, and they have important participation of foreign capital.

As was suspected from previous Colombian experience, the study reflects the poor initiative that firms established in Colombia have in carrying out TDA with universities. Nearly $98 \%$ of the firms under analysis belong to the Isolated Firms cluster, a cluster that also has the worst evaluation both in innovation performance and in characterization variables. Public policy efforts to strengthen innovation capabilities should focus on small and medium enterprises, most of which belong to the Isolated Firms cluster. These efforts must focus on increasing cooperative projects between firms and universities in order to improve that firms' competitiveness as Trained Firms do. This study has shown how the trend for establishing strong relationships with universities through two-parties projects, increasing the number of R\&D employees, and the number of external relations to TDA could rebound in astonishing results in innovation performance, and consequently, in the firm's competitiveness.

Finally, the study also showed the relatively scarce dynamism that firms under consideration have to protect knowledge through patents. There is no clear leadership around the patent request among the three clusters found. It is important to study this attitude in the average Colombian firm, since knowledge protection through intellectual property law has become an important prerequisite in successful firm-university relationships.

\begin{tabular}{|ccc|}
\hline No & \multicolumn{1}{c|}{ Hypothesis } & Result \\
\hline 1 & $\begin{array}{c}\text { There is a difference among the three clusters in } \\
\text { the number of employees for R\&D activities. }\end{array}$ & Supported \\
\hline 2 & $\begin{array}{l}\text { There is a difference among the three clusters in } \\
\text { the number of external relationships to develop } \\
\text { TDA }\end{array}$ & Supported \\
\hline 3 & $\begin{array}{l}\text { There is a difference among the three cluster in the } \\
\text { amount of money invested by public organizations }\end{array}$ & Supported \\
\hline 4 & $\begin{array}{l}\text { There is a difference in the innovation performance } \\
\text { among the three clusters. }\end{array}$ &
\end{tabular}

Table 9. Hypothesis Testing Summary

ISSN: 07I 8-2724. (http://www.jotmi.org)

Journal of Technology Management \& Innovation (c) Universidad Alberto Hurtado, Facultad de Economía y Negocios. 


\section{Acknowledgments}

This work was supported by a grant from the Colombian Institute for the Development of Science and Technology (Colciencias). The authors also wish to express their gratitude to the research team working on the DISCOVERY Project, for their ideas and comments on previous drafts.

\section{References}

ADEOTI,J.,Adeoti,A., 2005. Biotechnology R\&D partnership for industrial innovation in Nigeria. Technovation, 25, 349365.DOI:http://dx.doi.org/I0.1016/S0I66-4972(03)00I5I-2

ABELLO, R., 2007. Factores claves en las alianzas universidad - industria como soporte de la productividad en la industria local: hacia un modelo de desarrollo económico y social sostenible. Investigación y desarrollo, 15, 208-225.

ABRAMO, G., D’Angelo, C. A., Costa, F., Solazzi, M., 2009. University-industry collaboration in Italy: A bibliometric examination. Technovation, 29, 498-507. DOI: http://dx.doi. org/10.1016/j.technovation.2008.11.003

ALI, A., 1994. Pioneering versus incremental innovation: review and research propositions. Journal of Product Innovation Management, II, 46-6I. DOI: http://dx.doi. org/10.1016/0737-6782(94)901 I8-X

ANDERSON, T., Daim, T., Lavoie, F., 2007. Measuring the efficiency of university technology transfer. Technovation, 27, 306-318. DOI: http://dx.doi.org//0.1016/j.technovation.2006. 10.003

ARUNDEL, A., Geuna, A., 2004. Proximity and the use of public science by Innovative European firms. Economics of Innovation and New Technology, 13, 559-5804. DOI: I0.1080/I0438590920002343 II.

BAGCHI-SEN, S., 2004. Firm-specific characteristics of R\&D collaborators and non-collaborators in US biotechnology clusters and elsewhere. International Journal of Technology and Globalization, I, 92-I I8. http://inderscience.metapress. com/content/5CXEBB3E6CWOPEC2

BAILETTI, A.J., Callahan, J.R., 1993. The coordination structure of international collaborative technology arrangements. $R$ and D Management 23 (2), I29-|46. DOI: I0.1 I I I/j. I467$9310.1993 . t b 00081 . x$

BAYONA, C., Garcia-Marco, T., Huerta, E., 2003. ¿Cooperar en I+D? Con quien y para que . Revista de Economia Aplicada 31, 103-134.
BETTIS, R., Hitt, M., 1995. The New Competitive Landscape. Strategic. Managemente Journal, 16, 7-19. DOI: 10.1002/ smj.4250160915

BJERREGAARD, T., 20I0. Industry and academia in convergence: Micro-institutional dimensions of R\&D collaboration. Technovation, 30, 100-108. DOI: http://dx.doi.org//0.1016/j. technovation.2009.11.002

BOARDMAN, P. C., 2008. Beyond the stars: The impact of affiliation with university biotechnology centers on the industrial involvement of university scientists. Technovation 28, 29I-297. DOI: http://dx.doi.org/10.1016/j.technovation.2007.06.00I

CAPRON, H., Cincera, M., 2003. Industry-university S\&T transfers: Belgium evidence on CIS data. Brussels Economic Review 46 (3), 58-85. urn:issn: I 379-9932

CARAYANNIS, E.G., Alexander, J. and loannidis, A., 2000. Leveraging knowledge, learning, and innovation in forming strategic government-university-industry (GUI) R\&D partnerships in the US, Germany, and France. Technovation 20, 477-488. DOI: http://dx.doi.org/10.1016/S01664972(99)00I62-5

CHEN, E.Y., 1994. The evolution of university-industry technology transfer in Hong Kong. Technovation 14 (7), 449-459. DOI: http://dx.doi.org/I0.10I6/0166-4972(94)90003-5

COHEN, W. M., Levinthal, D.A., 1989. Innovation and Learning: The Two Faces of R\&D. The Economic Journal, 99, 569596.

COHEN, W. M., Nelson, R. R., Wals, J.P., 2002. Links and Impacts: The Influence of Public Research on Industrial R\&D. Management Science, 48, I-23. DOI: http://dx.doi. org/I0.1287/mnsc.48.I.I.14273

COLOMBIA, DANE, DNP, Colciencias, 2005. Manual de diligenciamiento de la Segunda Encuesta de Desarrollo e Innovación Tecnológica 2005. Bogotá D.C.

DAGHFOUS, A., 2004. An empirical investigation of the roles of prior knowledge and learning activities in technology transfer. Technovation 24, 939-953. DOI: http://dx.doi. org// 0.1016/S0166-4972(03)00059-2

DECTER, M., Bennett, D., Leseure, M., 2007. University to business technology transfer-UK and USA comparisons. Technovation, 27, I45-I55. DOI: http://dx.doi.org// 0.1016/j. technovation.2006.02.00I 
EOM, B.Y., Lee, K., 20I0. Determinants of industry-academy linkages and their impact on firm performance: The case of Korea as a latecomer in knowledge industrialization. Research Policy, 39, 625-639. DOI: http://dx.doi.org//0.1016/j. respol.2010.01.015

ETZKOWITZ, H., Webster, A., Gebhardt, C., Terra, B.R.C., 2000. The future of the university and the university of the future: evolution of ivory tower to entrepreneurial paradigm. Research Policy 29 (2), 3/3-330. DOI: http://dx.doi. org/10.1016/S0048-7333(99)00069-4

FONTANA, R., Geuna, A., Matt, M., 2006. Factors affecting university-industry R\&D projects: The importance of searching, screening and signalling. Research Policy, 35, 309323. DOI: http://dx.doi.org/I 0.10 I6/j.respol.2005.12.00 I

FREEL, M.S., Harrison, R.T., 2006. Innovation and cooperation in the small firm sector: evidence from northern Britain. Regional Studies 40 (4), 289-305. DOI: 10.1080/00343400600725095

GASSOL, J.H., 2007. The effect of university culture and stakeholders' perceptions on university-business linking activities. Journal of Technology Transfer 32, 489-507. DOI: | 0.1007/s 1096I-007-9035-I

GEISLER, E., 1995. Industry-university technology cooperation: a theory of interorganizational relationships. Technology Analysis and Strategic Management 7 (2), 217-229. DOI: I 0.1080/09537329508524205

GEORGE, G., Zahra, S. A., Wood, D. R., 2002. The effects of business-university alliances on innovative output and financial performance: a study of publicly traded biotechnology companies. Journal of Business Venturing, 17, 577-609. DOI: http://dx.doi.org/I0.1016/S0883-9026(0I)00069-6

HALL, L. A., Bagchi-Sen, S., 2007. An analysis of firm-level innovation strategies in the US biotechnology industry. Technovation 27, 4-I4. DOI: http://dx.doi.org//0.1016/j.technovation.2006.07.00I

JOHNSON,W. H.A., 2008. Roles, resources and benefits of intermediate organizations supporting triple helix collaborative R\&D:The case of Precarn. Technovation 28, 495-505. DOI: http://dx.doi.org/ I0.1016/j.technovation.2008.02.007

KLEVORICK, A. K., Levin, R. C., Nelson, R.R., Winter S.G., 1995. On the sources and significance of interindustry differences in technological opportunities. Research Policy, 24, 185-205. DOI: http://dx.doi.org/10.1016/00487333(93)00762-I
LAURSEN, K., Salter, A., 2004. Searching high and low: what types of firms use universities as a source of innovation?. Research Policy, 33, I20I-I215. DOI: 10.1016/j.respol.2004.07.004

LEE, J., Park, C., 2006. Research and development linkages in a national innovation system: Factors affecting success and failure in Korea. Technovation 26, I045-1054. DOI: http:// dx.doi.org/10.1016/j.technovation.2005.09.004

LEE, J., Win, H.N., 2004. Technology transfer between university research centers and industry in Singapore. Technovation, 24, 433-442. DOI: http://dx.doi.org/l0.1016/S01664972(02)0010I-3

LÓPEZ, A., 2008. Determinants of R\&D cooperation: Evidence from Spanish manufacturing firms. International Journal of Industrial Organization, 26, I 13-136. DOI: http:// dx.doi.org//0.1016/j.ijindorg.2006.09.006

MARKHAM, S., Kingon, A., Zapata, M., Baumer, D., 1999. A methodology to find assess and commercialize technologies, civilization, modern technology and sustainable development. In: The Eighth International Conference on Management of Technology, IAMOT, I5-I7 March, Cairo.

MIOTTI, L., Sachwald, F., 2003. Co-operative R\&D: why and with whom? An integrated framework of analysis. Research Policy, 32 , I 48 I- | 499.DOI: http://dx.doi.org/I0.1016/S00487333(02)00I59-2

MOHNEN, P., Hoareau, C., 2002. What type of enterprise forges close links with universities and government labs? evidence from CIS 2. Managerial and Decision Economics, 24, |33-|46. DOI: 10.1002/mde.1086

MONJON, S.,Waelbroeck, P., 2003.Assessing spillovers from universities to firms: evidence from french firm-level data. International Journal of Industrial Organization, 2 I, I255-1270. DOI: http://dx.doi.org/I0.1016/S0167-7/87(03)00082-I

MORA, E. M., Montoro, A. and Guerras, L.A., 2004. Determining factors in the success of R\&D cooperative agreements between firms and research organizations. Research Policy, 33, 17-40. DOI: http://dx.doi.org//0.1016/S00487333(03)00087-8

NIKULAINEN, T., Palmberg, C., 20I0. Transferring sciencebased technologies to industry - Does nanotechnology make adifference?.Technovation, 30, 3-I I.DOI: http://dx.doi. org/I0.1016/j.technovation.2009.07.008

OECD. Oslo Manual.Third Edition. Grupo Tragsa. 2005. 
POWELL, W., Koput, K.W., Smith-Doerr, L., 1996. Inter-organizational collaboration and the locus of innovation: networks of learning in biotechnology. Administrative Science Quarterly, 4I, II6-I45.

PRABHU, Ganesh N., 1999. Implementing university-industry joint product innovation projects. Technovation, 19, 495505. DOI: http://dx.doi.org/I0.10I6/S0 I66-4972(98)00 I25-4

RYCROFT, R. W., Kash, D. E., 2004. Self-organizing innovation networks: implications for globalization. Technovation, 24, I87-197. DOI: http://dx.doi.org//0.1016/S0I664972(03)00092-0

SANTORO, M. D., 2000. Success breeds success: the linkages between relationship intensity and tangible outcomes in industry-university collaborative ventures. Journal of High Technology Management Research II (2), 255-273. DOI: http://dx.doi.org/I0.1016/SI047-8310(00)00032-8

SANTORO, M. D., Chakrabarti, A.K., 2002. Firm size and technology centrality in industry-university interactions. Research Policy, 31, I I63-I I80. DOI:http://dx.doi.org/I0.1016/ S0048-7333(01)00190-I

SEGARRA-Blasco, A., Arauzo-Carod, J.M., 2008. Sources of innovation and industry-university interaction: Evidence from Spanish firms. Research Policy, 37, 1283-1295. DOI: http://dx.doi.org//0.1016/j.respol.2008.05.003

SCHARTINGER, D., Schibany,A., Gassler, H., 200I Interactive relations between universities and firms: empirical evidence for Austria. Journal of Technology Transfer 26 (3), 255-268. DOI: 10.1023/A:101 III 0207885

SHILLING, M., 2005. Strategic Management of Technological Innovation. Third edition.

SPENCER, J.W., 200I. How relevant is university-based scientific research to private high-technology firms? a United States-Japan comparison. Academy of Management Journal 44, 432-440. DOI: 10.2307/3069465

STUART, T.E., Hoang, H., Hybels, R.C., 1999. Interorganizational endorsements and the performance of entrepreneurial ventures. Administrative Science Quarterly, 44 (2), 3I5-349. DOI: 10.2307/2666998

VALENTIN, E., 2000. University-industry cooperation: a framework of benefits and obstacles. Industry and Higher Education, 14, 165-172. DOI: http://dx.doi. org/I0.5367/000000000I0I2950I I
VEUGELERS, R. and Cassiman, B., 2005. R\&D cooperation between firms and universities. Some empirical evidence from Belgian manufacturing. International Journal of Industrial Organization, 23, 355-379. DOI: http://dx.doi. org/I0.1016/j.ijindorg.2005.01.008

ZUCKER, L.G., Darby, M.R., Armstrong, J., 1998. Geographically localized knowledge: spillovers or markets. Economic Inquiry, 36 (I), 65-86. DOI: I0.IIII/j.I465-7295.1998. tb01696.x 